\title{
Robotic Surgery: Research and Reviews 2014: editorial foreword
}

This article was published in the following Dove Press journal:

Robotic Surgery: Research and Reviews

30 April 2014

Number of times this article has been viewed

\author{
Dana M Roque \\ Masoud Azodi ${ }^{1,2}$ \\ 'Division of Gynecologic Oncology, \\ ${ }^{2}$ Division of Minimally Invasive \\ and Robotic Surgery, Department \\ of Obstetrics, Gynecology and \\ Reproductive Sciences, Yale University, \\ New Haven, CT, USA
}

Leonardo da Vinci has been credited with the design in 1495 of the first known robot, which was capable of human-like motions through the manipulation of multiple coordinated pulleys. ${ }^{1}$ The term "robot" stems from the Czech word "robota", referring to compulsory labor, and was popularized in English vocabulary as early as 1923. Today, the Robotics Institute of America defines "robots" as "reprogrammable, multifunctional manipulators designed to move material, parts, tools, or specialized devices through various programmed functions for the performance of a variety of tasks". ${ }^{2}$

Robotic technology entered the surgical industry as early as 1985, beginning with applications to improve accuracy and precision in neurosurgery during stereotactic brain biopsies ${ }^{3}$ and in the field of orthopedics for joint alignment. ${ }^{4}$ Robotic assistance soon emerged as a tool to overcome problematic ergonomics limiting dexterity and the pitfalls of bi-dimensional imaging associated with traditional laparoscopic approaches, with roles quickly expanding to urologic, gastrointestinal, cardiac, maxillofacial, ophthalmologic, and gynecologic subspecialties, among others. ${ }^{5}$

Remote surgery was pioneered in parallel at the Stanford Research Institute with input from plastic surgeon Joseph Rosen and engineer Phil Green, ${ }^{6}$ and attracted interest from the United States Army given its potential use within a hostile battlefield environment. ${ }^{7}$ The first robotic assistant arm $\left(\right.$ AESOP $^{\circledR}$ [Automated Endoscopic System for Optimal Positioning]; Computer Motion, Inc, Goleta, CA, USA) was designed to manipulate the laparoscope and received approval from the US Food and Drug Administration in 1994. Zeus ${ }^{\circledR}$ (Computer Motion, Inc) was the first robotic system with a remote console capable of long-distance surgery, including the transcontinental "Operation Lindbergh", in which a surgeon in Manhattan, New York, performed a laparoscopic cholecystectomy on a patient in Strasbourg, Germany. The da Vinci ${ }^{\circledR}$ surgical system prototype (Intuitive Surgical, Inc, Sunnyvale, CA, USA) with three arms then obtained US Food and Drug Administration approval in July 2000, and largely supplanted all previous systems.

The field of robotic surgery continues to rapidly evolve. Presently, there remains a great need for additional trials to objectively compare clinical outcomes and the costeffectiveness of robotic compared to traditional laparoscopic and open procedures, including expanding roles in bariatric populations. Novel techniques and refinements in existing methods, such as single-site robotic-assisted surgery, are continually emerging. The full scope of telesurgery and telementoring in global access to health care remains undefined.
Correspondence: Masoud Azodi

Division of Minimally Invasive and Robotic Surgery, Department of

Obstetrics, Gynecology and Reproductive Sciences, Yale University, 333 Cedar Street-FMB 328, PO Box 208063, New Haven, CT 06520, USA

Email masoud.azodi@yale.edu submit your manuscript | www.dovepress.com

Dovepress

http://dx.doi.org/10.2147/RSRR.S54695
Robotic Surgery: Research and Reviews 2014:I II-I2

(c) (i) (5) 2014 Roque and Azodi. This work is published by Dove Medical Press Limited, and licensed under Creative Commons Attribution - Non Commercial (unported, v3.0) License. The full terms of the License are available at http://creativecommons.org/licenses/by-nc/3.0/. Non-commercial uses of the work are permitted without any further permission from Dove Medical Press Limited, provided the work is properly attributed. Permissions beyond the scope of the License are administered by Dove Medical Press Limited. Information on
how to request permission may be found at: http://www.dovepress.com/permissions.php 
The purpose of this journal is to provide an intellectual forum for such discussions. We look forward to sharing your insights, original research, and systematic reports. Welcome to the inaugural edition of Robotic Surgery: Research and Reviews 2014.

\section{Disclosure}

The authors declare no conflicts of interest in this work.

\section{References}

1. Rosheim ME. Leonardo's programmable automaton and lion. In: Leonardo's Lost Robots. Berlin: Springer-Verlag; 2006:69-71.

2. Taghirad HD. Parallel Robots: Mechanics and Control. Boca Raton, FL: Taylor and Francis; 2013.
3. Kwoh YS, Hou J, Jonckheere EA, Hayati S. A robot with improved absolute positioning accuracy for $\mathrm{CT}$ guided stereotactic brain surgery. IEEE Trans Biomed Eng. 1988;35(2):153-10.

4. Sroga J, Patel SD, Falcone T. Robotics in reproductive medicine. Front Bioscience. 2008;13:1308-1317.

5. Challacombe BJ, Khan MS, Murphy D, Dasgupta P. The history of robotics in urology. World J Urol. 2006;24(2):120-127.

6. Green PS, Hill JW, Satava RM. Telepresence: dexterous procedures in a virtual operating field. Surg Endosc. 1991;57:192.

7. Pugin $P$, Bucher P, Morel P. History of robotic surgery: from AESOP ${ }^{\circledR}$ and ZEUS ${ }^{\circledR}$ to da Vinci ${ }^{\circledR}$. J Visc Surg. 2011;148(5 Suppl):e3-e8.

\section{Publish your work in this journal}

Robotic Surgery: Research and Reviews is an international, peer reviewed, open access, online journal publishing original research, commentaries, reports, and reviews on the theory, use and application of robotics in surgical interventions. Articles on the use of supervisory-controlled robotic systems, telesurgical devices, and shared-control systems are invited. The manuscript management system is completely online and includes a very quick and fair peer review system, which is all easy to use. Visit http://www.dovepress.com/testimonials.php to read real quotes from published authors.

Submit your manuscript here: http://www.dovepress.com/robotic-surgery-research-and-reviews-journal 